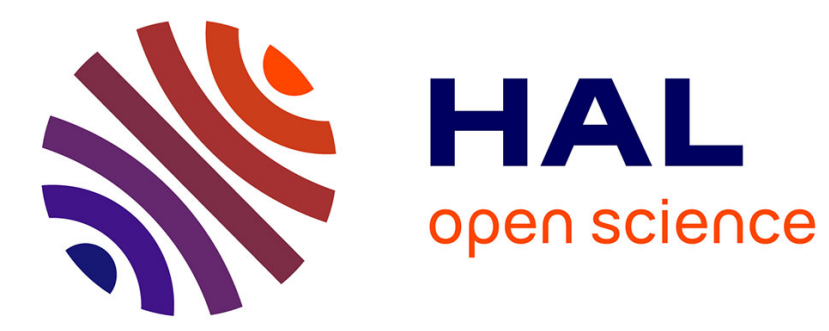

\title{
Ileal short-chain fatty acids inhibit gastric motility by a humoral pathway
}

\author{
G. Cuche, J.C. Cuber, Charles-Henri Malbert
}

\section{To cite this version:}

G. Cuche, J.C. Cuber, Charles-Henri Malbert. Ileal short-chain fatty acids inhibit gastric motility by a humoral pathway. AJP - Gastrointestinal and Liver Physiology, 2000, 279 (5), pp.G925-G930. hal-02693665

\section{HAL Id: hal-02693665 https://hal.inrae.fr/hal-02693665}

Submitted on 1 Jun 2020

HAL is a multi-disciplinary open access archive for the deposit and dissemination of scientific research documents, whether they are published or not. The documents may come from teaching and research institutions in France or abroad, or from public or private research centers.
L'archive ouverte pluridisciplinaire HAL, est destinée au dépôt et à la diffusion de documents scientifiques de niveau recherche, publiés ou non, émanant des établissements d'enseignement et de recherche français ou étrangers, des laboratoires publics ou privés. 


\section{G. Cuche, J. C. Cuber and C. H. Malbert}

Am J Physiol Gastrointest Liver Physiol 279:925-930, 2000.

You might find this additional information useful...

This article cites 29 articles, 13 of which you can access free at:

http://ajpgi.physiology.org/cgi/content/full/279/5/G925\#BIBL

This article has been cited by 4 other HighWire hosted articles:

Colonic fermentation of indigestible carbohydrates contributes to the second-meal effect.

F. Brighenti, L. Benini, D. Del Rio, C. Casiraghi, N. Pellegrini, F. Scazzina, D. J. Jenkins and I.

Vantini

Am. J. Clinical Nutrition, April 1, 2006; 83 (4): 817-822.

[Abstract] [Full Text] [PDF]

\section{Chylomicron components mediate intestinal lipid-induced inhibition of gastric motor \\ function}

J. Glatzle, T. J. Kalogeris, T. T. Zittel, S. Guerrini, P. Tso and H. E. Raybould

Am J Physiol Gastrointest Liver Physiol, January 1, 2002; 282 (1): G86-G91.

[Abstract] [Full Text] [PDF]

Inhibition of gastric emptying by acarbose is correlated with GLP-1 response and accompanied by $\mathrm{CCK}$ release

F. Y. Enc, N. Imeryuz, L. Akin, T. Turoglu, F. Dede, G. Haklar, N. Tekesin, N. Bekiroglu, B. C. Yegen, J. F. Rehfeld, J. J. Holst and N. B. Ulusoy

Am J Physiol Gastrointest Liver Physiol, September 1, 2001; 281 (3): G752-G763.

[Abstract] [Full Text] [PDF]

Desensitization of ileal vagal receptors by short-chain fatty acids in pigs

G. Cuche, S. Blat and C. H. Malbert

Am J Physiol Gastrointest Liver Physiol, May 1, 2001; 280 (5): G1013-G1021.

[Abstract] [Full Text] [PDF]

Medline items on this article's topics can be found at http://highwire.stanford.edu/lists/artbytopic.dtl

on the following topics:

Biochemistry .. Fatty Acids

Biochemistry .. Short Chain Fatty Acids

Endocrinology .. Glucagon-Like Peptides

Veterinary Science .. Ileum

Physiology .. Pigs

Updated information and services including high-resolution figures, can be found at:

http://ajpgi.physiology.org/cgi/content/full/279/5/G925

Additional material and information about AJP - Gastrointestinal and Liver Physiology can be found at: http://www.the-aps.org/publications/ajpgi

This information is current as of September 6, 2010 .

AJP - Gastrointestinal and Liver Physiology publishes original articles pertaining to all aspects of research involving normal or abnormal function of the gastrointestinal tract, hepatobiliary system, and pancreas. It is published 12 times a year (monthly) by the American Physiological Society, 9650 Rockville Pike, Bethesda MD 20814-3991. Copyright @ 2000 by the American Physiological Society. ISSN: 0193-1857, ESSN: 1522-1547. Visit our website at http://www.the-aps.org/. 


\title{
Ileal short-chain fatty acids inhibit gastric motility by a humoral pathway
}

\author{
G. CUCHE ${ }^{1}$ J. C. CUBER ${ }^{2}$ AND C. H. MALBERT ${ }^{1}$ \\ ${ }^{1}$ Unité de physiologie, physiopathologie de la digestion et du métabolisme des proténes, Station de \\ Recherches Porcines, Institut National de la Recherche Agronomique, 35590 Saint-Gilles; and \\ ${ }^{2}$ Unité Institut National de la Santé et de la Recherche Médicale U 45, 69437 Lyon, France
}

Received 22 November 1999; accepted in final form 31 May 2000

Cuche, G., J. C. Cuber, and C. H. Malbert. Ileal shortchain fatty acids inhibit gastric motility by a humoral pathway. Am $J$ Physiol Gastrointest Liver Physiol 279: G925-G930, 2000.-The aim of this study was to evaluate the nervous and humoral pathways involved in short-chain fatty acid (SCFA)-induced ileal brake in conscious pigs. The role of extrinsic ileal innervation was evaluated after SCFA infusion in innervated and denervated Babkin's ileal loops, and gastric motility was measured with strain gauges. Peptide YY (PYY) and glucagon-like peptide-1 (GLP-1) concentrations were evaluated in both situations. The possible involvement of absorbed SCFA was tested by using intravenous infusion of acetate. Ileal SCFA infusion in the intact terminal ileum decreased the amplitude of distal and terminal antral contractions $(33 \pm 1.2$ vs. $49 \pm 1.2 \%$ of the maximal amplitude recorded before infusion) and increased their frequency $(1.5 \pm 0.11$ vs. $1.3 \pm 0.10 / \mathrm{min})$. Similar effects were observed during SCFA infusion in ileal innervated and denervated loops (amplitude, $35 \pm 1.0$ and $34 \pm 0.8$ vs. $47 \pm 1.3$ and $43 \pm 1.2 \%$; frequency, $1.4 \pm 0.07$ and $1.6 \pm$ 0.06 vs. $1.1 \pm 0.14$ and $1.0 \pm 0.12 / \mathrm{min})$. Intravenous acetate did not modify the amplitude and frequency of antral contractions. PYY but not GLP-1 concentrations were increased during SCFA infusion in innervated and denervated loops. In conclusion, ileal SCFA inhibit distal gastric motility by a humoral pathway involving the release of an inhibiting factor, which is likely PYY.

Babkin loops; peptide YY; glucagon-like peptide-1.

NUTRIENTS IN THE ILEUM INHIBIT gastric motility and emptying, a phenomenon called the "ileal brake" $(25,28)$. Gastroparesia was also triggered by short-chain fatty acids (SCFA) infused in the distal ileum in pigs $(7,9)$. Unlike nonabsorbed nutrients originating from the upper part of the gut, SCFA were spontaneously present in the distal ileum as a result of frequent coloileal reflux episodes (8). These events, more frequent after a meal, supply SCFA concentration large enough to initiate an ileal brake.

The mechanisms of the ileal brake are still controversial (21). The role of a nervous pathway between the ileum and the stomach has been identified in gastric emptying (26) and proximal gastric tone (2) for carbo-

Address for reprint requests and other correspondence: C. H. Malbert, Station de Recherches Porcines, INRA, 35590 Saint-Gilles, France (E-mail: malbert@st-gilles.rennes.inra.fr) hydrates. However, in these models, ileal or jejunal infusion will eventually reach the colon, for which clear evidence of a nervous pathway inhibiting gastric motility has been established $(4,6,12,31)$. This, together with data obtained in humans and in dogs indicating that peptide YY (PYY) and possibly glucagon-like peptide-1 (GLP-1) increase during ileal infusion of nutrients, suggests that the ileal brake might be primarily of a humoral nature.

The aim of this study was to evaluate the roles of nervous and humoral pathways between the ileum and the stomach that are activated by the presence of SCFA in the distal ileum as a result of spontaneously occurring coloileal reflux. This was achieved by monitoring gastric motor activity during SCFA infusion in innervated and denervated ileal Babkin loops. The amount of SCFA infused was identical to that present during postprandial reflux episodes. Since SCFA infused in the loops might be absorbed and act directly on gastric motility, we also tested the effect of intravenous infusion of SCFA. Finally, the concentrations of the candidate peptides for a humoral modulation of nutrients inducing ileal brake (PYY and GLP-1) were measured in the same experimental conditions.

\section{MATERIALS AND METHODS}

Experimental design. Fifteen female Large White pigs ( $41 \pm 1.0 \mathrm{~kg}, 3 \mathrm{mo}$ old) were divided into three groups of equal size. Group I, with an intact small bowel, received intravenous or ileal infusions of SCFA. Innervated ileal Babkin loops (3) were constructed in group II to prevent SCFA passage into the cecocolonic segment. Denervation of a similarly created loop was performed in group III. Four animals taken at random in groups $I I$ (2 animals) and III (2 animals) were also used, in the interval between motility experiments, for blood sampling and subsequent PYY and GLP-1 assays.

Surgical preparation. Under aseptic conditions and general anesthesia, a midline abdominal laparotomy was performed in the three groups. The anesthesia protocol has previously been described in detail (8). Briefly, preanesthesia was induced by ketamine ( $5 \mathrm{mg} / \mathrm{kg} \mathrm{im}$ ). Administration of halothane ( $5 \% \mathrm{vol} / \mathrm{vol})$ by a face mask suppressed pharyngotracheal reflex, allowing intubation. Anesthesia was main-

The costs of publication of this article were defrayed in part by the payment of page charges. The article must therefore be hereby marked "advertisement" in accordance with 18 U.S.C. Section 1734 solely to indicate this fact. 
tained with inhaled halothane $(3 \% \mathrm{vol} / \mathrm{vol})$. Three strain gauge force transducers (Vishay Measurements) were sutured 8 (proximal antrum), 5 (distal antrum), and 3 (terminal antrum) $\mathrm{cm}$ proximal to the pylorus. Wires were brought subcutaneously to exit between the shoulders. A silicon catheter $(\mathrm{ID}=0.76 \mathrm{~mm}$ ) was introduced into the external jugular vein and brought subcutaneously between the shoulders.

The surgical preparation at the ileal level differed among groups. In group $I$, with the use of a right lateral laparotomy, a silicon catheter (ID $=1.5 \mathrm{~mm}$ ) used for ileal SCFA infusions was inserted in the distal ileum $15 \mathrm{~cm}$ proximal to the ileocecal sphincter. In groups $I I$ and III, ileal Babkin loops (3) were created. The last $20 \mathrm{~cm}$ of the ileum were isolated from the terminal ileum and placed under the skin. The two ends of the loop were passed through the skin to create two stomies. Bowel continuity was restored by an end-to-end anastomosis. A fine silicon sheet was wrapped loose around the loop's mesenteric arcade to help locate the arcade during the following surgical procedure, which was performed in group III only. For group III, 1 mo later and once revascularization of the loop was completed, the mesenteric arcade of the loop was cut to suppress extrinsic innervation.

Animals were allowed 1 wk to recover from surgery before the start of the recordings. Once a day and when experiments were not performed, the loops were rinsed using Sustacal (1 $\mathrm{ml} / \mathrm{min}$ for $1 \mathrm{~h}$; Mead Johnson).

At the end of the experiments, the animals were killed with an overdose of pentobarbital sodium, and tissues were sampled from the loops for histopathological evaluation. No major alteration could be observed in all loop samples, but the height of the villi and the thickness of the muscular layer were less compared with intact ileum collected in pigs of identical age and weight at the slaughterhouse.

Experimental protocol. Studies were performed in conscious pigs at 2-day intervals and after at least $14 \mathrm{~h}$ of fasting. Pigs did not have access to water during experiments.

In groups $I, I I$, and $I I I$, the effects of an ileal infusion of a mixture containing $60 \%$ acetate $\left(\mathrm{C}_{2}\right), 30 \%$ propionate $\left(\mathrm{C}_{3}\right)$, and $10 \%$ butyrate $\left(\mathrm{C}_{4}\right)(\mathrm{pH} 6.8 ; 0.5 \mathrm{M})$ administered at a rate of $2.4 \mathrm{ml} / \mathrm{min}$ for $1 \mathrm{~h}$ were evaluated compared with the infusion at the same rate and duration of saline. This mixture has the same SCFA chemical composition as the colonic refluxate in pigs. In group $I$ only, the effect of intravenous acetic acid ( $\mathrm{pH} 6.8 ; 1.2 \mathrm{M}, 1 \mathrm{ml} / \mathrm{min}$ for $1 \mathrm{~h}$ ), the only SCFA found in the blood after intestinal infusion of $\mathrm{C}_{2}, \mathrm{C}_{3}$, and $\mathrm{C}_{4}$ mixture (15), was tested vs. an identical intravenous infusion of saline.

All infusions were started 5 min after the onset of an antral phase I of a migrating motor complex (MMC). Motility measurements were performed for $3 \mathrm{~h}$ before and after the infusion.

Blood samples were collected twice before the start of the ileal infusion. Afterwards, blood was sampled at 0, 15, 30, 45, $60,75,90,120,150$, and $180 \mathrm{~min}$ relative to the onset of SCFA infusion. Plasma was immediately separated $(4,500$ $\mathrm{rpm}, 5 \mathrm{~min}$ ) and stored at $-20^{\circ} \mathrm{C}$ for later analysis.

Recordings. Strain gauge signals were recorded on a multichannel chart recorder (Gould 4042 and Beckman R611) using a half bridge coupler (1B31; Analog Devices) and simultaneously digitized $(15 \mathrm{~Hz})$ on a computer (Macintosh II; Apple Computer) using an A/D card (NB MI016; National Instruments) after low-pass filtration at $10 \mathrm{~Hz}$. Data were stored digitally for subsequent analysis.

Peptides assay. RIA for PYY was performed as previously described with antiserum A4D obtained from a rabbit after repeated injection of synthetic porcine PYY conjugated to
BSA through ethylcarbodiimide condensation (5). This antiserum, which cross-reacted $<0.1 \%$ with porcine pancreatic polypeptide and NPY, was used in the assay at a final dilution of $1: 800,000$. The synthetic peptide was iodinated with carrier-free $\mathrm{Na}^{-125} \mathrm{I}$ by means of the chloramine- $\mathrm{T}$ reagent and was purified by reverse-phase HPLC as previously described (5). The minimum detectable amount of PYY and the $\mathrm{ID}_{50}$ of the assay were 1 and $7 \mathrm{fmol} /$ tube, respectively. Plasma samples run on a Sephadex G-50 column revealed a single immunoreactive peak coeluting with the synthetic peptide.

The GLP-1 assay was performed as described earlier (1, 23). Briefly, antiserum against GLP-1-(7-36) amide was obtained in a rabbit by immunization with synthetic GLP-1-(736) amide conjugated to BSA and was used at a final dilution of $1: 300,000$. The reactivity of the antiserum $199 \mathrm{D}$ was $100 \%$ for GLP-1-(7-36) amide, 84\% for GLP-1-(1-36) amide, and $<0.1 \%$ for GLP-1-(1-37), GLP-1-(7-37), GLP-2, glucagon, secretin, vasoactive intestinal peptide, and gastrointestinal inhibitory peptide. The synthetic GLP-1-(7-36) amide was radioiodinated using the chloramine- $T$ method and purified by reverse HPLC. The detection limit and ID $_{50}$ were 0.6 and $4.5 \mathrm{fmol} /$ tube, respectively. The plasma samples $(1 \mathrm{ml})$ were treated with 2 volumes of ethanol. The ethanol extracts were dried and kept at $-30^{\circ} \mathrm{C}$. The plasma ethanol extracts were reconstituted in assay buffer (50 $\mathrm{mM}$ phosphate, $\mathrm{pH} 7.5$, containing $5 \mathrm{mM}$ EDTA and $2 \%$ horse serum) on the day of the assay.

Data analysis. Strain gauge data were automatically analyzed using MAD 3.2 software to evaluate the amplitude and frequency of antral contractions $(7,9)$. The amplitude of contractions was expressed as the percentage of the maximal amplitude recorded before the infusion. Motility index was calculated, for the distal antral strain gauge only, as the sum of amplitude multiplied by frequency of all contractions recorded during $1 \mathrm{~h}$. It was expressed as a percentage of the maximum amplitude recorded before the infusion per minute. Propagation profiles of antral contractions were expressed as the percentage of antral contractions occurring in sequence on three adjacent recording sites. The time window during which contraction had to occur to be part of a propagated pattern was $\pm 5 \mathrm{~s}$ (for adjacent recording locations). Contractions that did not fulfill this criteria were considered stationary contractions.

Statistical analysis was performed using Statview software (SAS Institute). Data are expressed as means $\pm \mathrm{SE}$. Comparisons between SCFA and saline infusions or between acetate and saline infusions within the same experimental group were achieved by one-way analysis of variance. Comparisons between experimental groups were performed by two-way analysis of variance. Fischer protected least significant differences test was used in both situations to test the level of significance of $P<0.05$. Comparisons for PYY and GLP-1 profiles were achieved with repeated-measures analysis of variance.

\section{RESULTS}

Parenteral acetate. The amplitude and frequency of antral contractions were not significantly modified during intravenous acetate compared with saline infusion (Figs. 1 and 2). Distal antral motility index was also similar for acetate and saline infusions $(3,225 \pm$ 476.4 vs. $3,899 \pm 440.1 \% / \mathrm{min}$ for saline and acetate infusions, respectively; $P>0.05$ ). Recurrence and duration of the MMC phases were identical $(P>0.05)$ for 

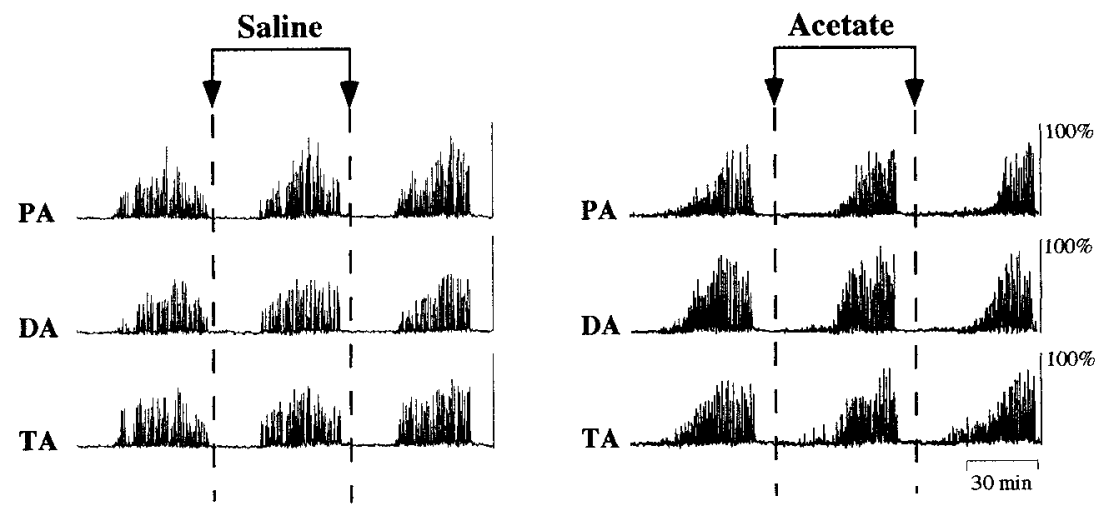

Fig. 1. Antral motility recordings obtained from a single representative animal during intravenous saline or acetate infusion. Gastric motility was not modified by acetate infusion compared with saline. PA, proximal antrum; DA, distal antrum; TA, terminal antrum.

both treatments; hence the MMC duration was not significantly different $(69 \pm 8$ vs. $62 \pm 4 \mathrm{~min})$. Antral contraction propagation patterns were identical for saline and acetate infusions (stationary contractions, $17 \pm 3.7$ vs. $18 \pm 2.3 \%$; contractions propagated over the 3 recording sites, $46 \pm 6.2$ vs. $41 \pm 5.2 \%$, respectively, during saline and $\mathrm{C}_{2}$ infusions; $P>0.05$ ).

Enteral SCFA. SCFA mixture infused in the intact terminal ileum (group I) decreased the amplitude and increased the frequency of antral contractions irrespective of the recording site (Figs. 3 and 4). The motility index recorded at the distal antral level was reduced by $35 \%$ compared with saline $(2,624 \pm 503.4$ vs. $4,077 \pm$ $388.2 \% / \mathrm{min} ; P<0.05)$. Gastric MMC duration was unchanged during SCFA infusion compared with saline $(74 \pm 4$ vs. $82 \pm 4 \mathrm{~min} ; P>0.05)$. However, the first MMC recorded at the completion of the infusion lasted significantly longer for SCFA than saline (94 \pm 5 vs. $67 \pm 4 \mathrm{~min} ; P<0.05)$. Afterwards, the characteristics of the MMC were similar to preinfusion ones. The percentage of stationary contractions was greater during ileal SCFA infusion compared with saline, whereas that of propagated ones was reduced (Table 1).

Antral motility was also modified by SCFA mixture compared with saline infusion within innervated ileal loop (group II), the amplitude of antral contractions being decreased and their frequency being increased by SCFA. Similarly, SCFA infusion decreased distal antral motility index compared with saline $(2,343 \pm 273.4$ vs. $3,294 \pm 254.2 \% / \mathrm{min} ; P<0.05)$. This reduced antral
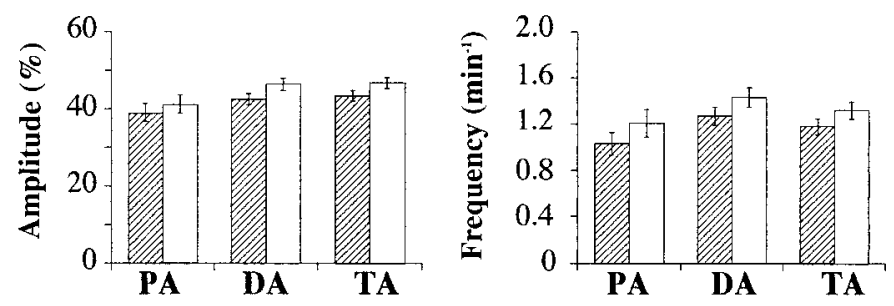

Saline

Acetate

Fig. 2. Characteristics of antral contractions during intravenous saline or acetate infusion. Neither the amplitude nor the frequency of antral contractions was significantly $(P<0.05)$ modified by acetate infusion compared with saline. motility was within the range of that found for group $I$ $(2,343 \pm 273.4$ vs. $2,624 \pm 503.4 \% / \mathrm{min} ; P>0.05)$. In the same way as for group I, MMC duration was not modified during SCFA infusion $(73 \pm 6$ vs. $74 \pm 8$ min for SCFA vs. saline; $P>0.05$ ) and was significantly increased at the completion of infusion (90 \pm 5 vs. $78 \pm$ 4 min for SCFA vs. saline; $P<0.05$ ). Antral contraction propagation patterns were altered by SCFA compared with saline as for group I (Table 1).

The SCFA-induced motility changes described for groups $I$ and $I I$ were not abolished in animals with a denervated ileal loop (group III). Distal antral motility index was decreased by SCFA mixture infusion within the denervated ileal loop $(2,210 \pm 342.4$ vs. $3,081 \pm$ $283.8 \% / \mathrm{min}$ for SCFA vs. saline; $P<0.05$ ). This reduction was comparable to that observed for groups $I$ and II $(P>0.05)$. Changes in MMC duration similar to those described in groups $I$ and $I I$ were also found in group III $(77 \pm 4$ vs. $63 \pm 4$ min for SCFA vs. saline; $P<0.05)$. Contraction propagation patterns were changed by SCFA vs. saline, and these changes were not significantly different between groups $I$ and III (Table 1).

PYY concentrations. PYY plasma concentration was increased from 15 to $60 \mathrm{~min}$ after the onset of ileal saline or SCFA infusion compared with preinfusion values $(414 \pm 57.0$ vs. $294 \pm 51.3 \mathrm{pg} / \mathrm{ml})$. Nevertheless, this increase was significantly greater for SCFA infusion at 30 and 45 min compared with saline (Fig. 5). Plasma PYY concentrations recovered values similar to basal level 15 min after the completion of infusion. The area under the curve of PYY response to ileal SCFA was increased compared with saline infusion $\left(6,648 \pm 2,932.6\right.$ vs. $-285 \pm 2,281.8 \mathrm{pg} \cdot \mathrm{ml}^{-1} \cdot \mathrm{h} ; P<$ 0.05). The effect of SCFA infusion on PYY concentration was not significantly different $(P>0.05)$ for groups II and III.

GLP-1 concentrations. Plasma GLP-1 concentration increased during SCFA and saline infusions compared with preinfusion values. Nevertheless, no significant differences were noticed between saline and SCFA infusions irrespective of sampling time (Fig. 5). Similarly, the area under the curve was identical for both situations $\left(111 \pm 98.7\right.$ vs. $299 \pm 107.9 \mathrm{pg} \cdot \mathrm{ml}^{-1} \cdot \mathrm{h}$, respectively, for saline and SCFA; $P>0.05$ ). Finally, 
Fig. 3. Antral motility during saline or short-chain fatty acid (SCFA) mixture infusion in intact terminal ileum (group $I ; A$ ), innervated ileal loop (group $I I ; B$ ), and denervated ileal loop (group III; C). Gastric motor inhibitions induced by SCFA were similar for all groups. Data shown were obtained in 1 representative animal for each experimental group.
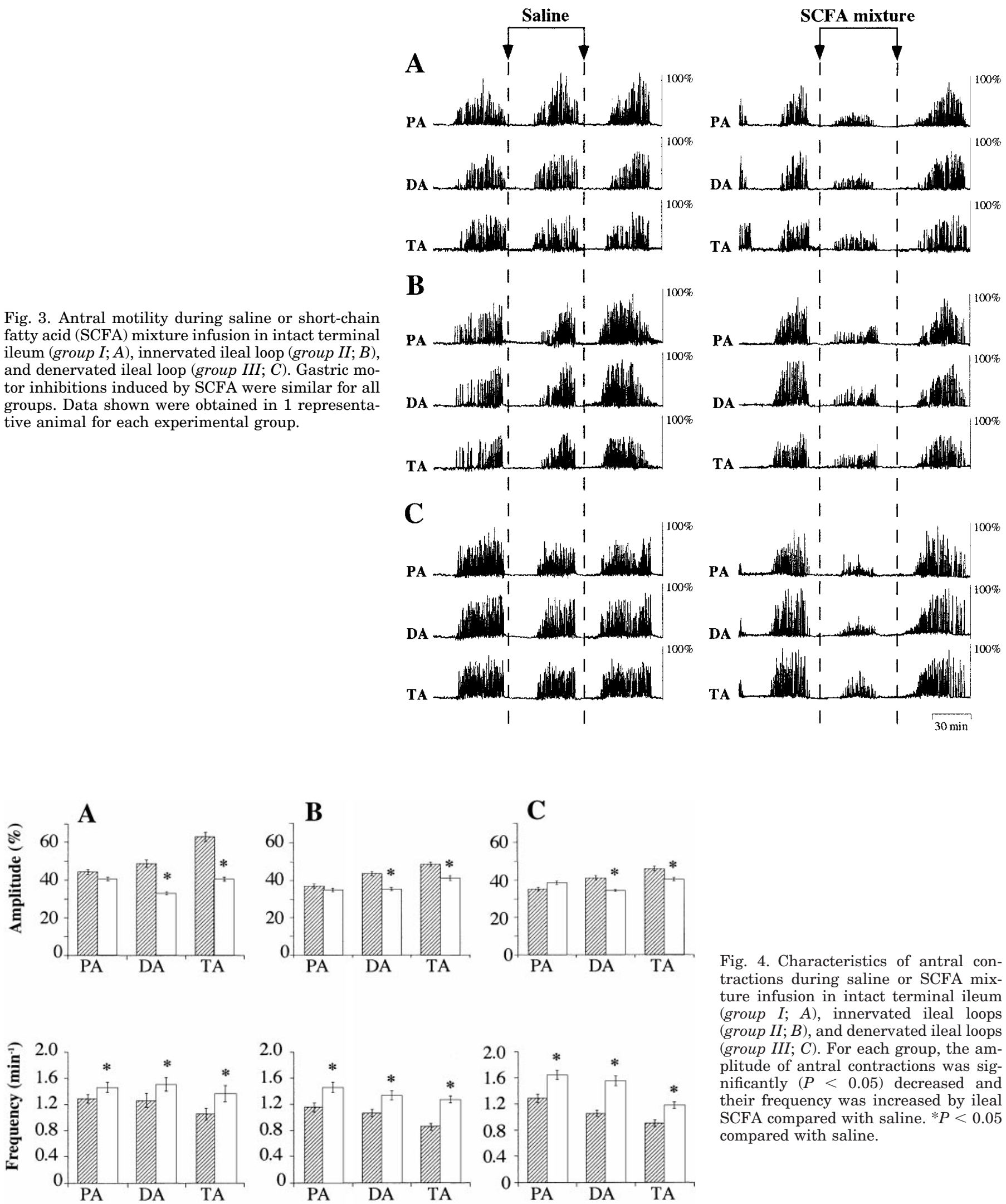

Fig. 4. Characteristics of antral contractions during saline or SCFA mixture infusion in intact terminal ileum (group $I ; A)$, innervated ileal loops (group $I I ; B)$, and denervated ileal loops (group III; $C$ ). For each group, the amplitude of antral contractions was significantly $(P<0.05)$ decreased and their frequency was increased by ileal SCFA compared with saline. ${ }^{*} P<0.05$ compared with saline. 
Table 1. Propagation profile of antral contractions during ileal saline or SCFA infusions in intact terminal ileum, innervated loops, and denervated loops

\begin{tabular}{llll}
\hline \hline & Group I & Group II & Group III \\
\hline \% of stationary contractions & & & \\
saline & $19 \pm 4.5$ & $17 \pm 2.0$ & $19 \pm 1.8$ \\
SCFA & $27 \pm 4.2^{*}$ & $26 \pm 3.3^{*}$ & $27 \pm 3.1^{*}$ \\
\% of contractions propagated & & & \\
$\quad$ over the 3 recording sites & & & \\
saline & $40 \pm 6.9$ & $39 \pm 3.0$ & $37 \pm 4.6$ \\
SCFA & $26 \pm 6.0^{*}$ & $29 \pm 4.7^{*}$ & $27 \pm 5.7^{*}$ \\
\hline
\end{tabular}

Values are means $\pm \mathrm{SE} ; n=5$ pigs/group. SCFA, short-chain fatty acids; group I, intact terminal ileum; group II, innervated loops; group III, denervated loops. ${ }^{*} P<0.05$ for saline vs. SCFA mixture.

there was no difference between GLP-1 responses in groups II and III $(P>0.05)$.

\section{DISCUSSION}

Using innervated and denervated ileal loops, we have demonstrated that, in conscious pigs, extrinsic ileal innervation was not necessary for ileal SCFA to inhibit gastric motility. PYY but not GLP-1 was released in the bloodstream during SCFA ileal infusion and might be responsible for gastric motility inhibition.

There is considerable evidence that the distal intestine participates in the regulation of proximal gut function (19). In physiological situations, stimulation of the ileum occurs in the late postprandial regulation of gastrointestinal response (17), whereas in malabsorptive states, impaired gastric emptying and intestinal transit are adaptative answers to compensate for the absorption deficit (27). The ileal brake consists of a variety of motor, secretory, and behavioral responses, including gastric motor inhibition (10), reduction of gastric emptying rate (30), lower interdigestive gastric acid output (18), and suppression of short-term food intake (29). The chemical nature of the nutrients triggering the ileal brake is species dependent and controversial since in dogs glucose, lipids, and proteins have been found effective (27), whereas in humans proteins and glucose are not (30). Nevertheless, lipids are the most potent class of compounds. Whereas their mechanism of action toward ileal mucosa is not well understood, Lin et al. (21) suggested that they might involve the end product of lipid digestion i.e., SCFA. This, together with the presence of SCFA within the ileum as a result of coloileal reflux (8), might explain the exquisite sensitivity of the ileal brake to SCFA in pigs.

The results from parenteral acetate infusion invalidate the possibility that absorbed SCFA per se might represent an effective humoral inhibitory agent toward gastric motility. Indeed, $30 \mu \mathrm{mol} \cdot \mathrm{kg}^{-1} \cdot \mathrm{min}^{-1}$ intravenous acetate, the sole SCFA present in the blood after SCFA mixture ileal infusion (15), was ineffective in triggering significant antral motility changes, whereas a similar amount infused within the ileum inhibited gastric motility. Similarly, the antral inhibition was not related to colonic stimulation by SCFA transported together with the intestinal fluid from the ileum to the colon, since gastroparesia was also present while SCFA were perfused in the ileal loop (group II).

Our demonstration of a pure humoral pathway at the origin of an ileal brake in pigs is in accordance with the reversion of lipid-induced ileal brake with the use of PYY immunoneutralization in dogs (21). Nevertheless, the previous experiments are partially in contradiction with an extrinsic nervous pathway triggered either by carbohydrate (26) or a carbohydrate-containing mixture (2) demonstrated in dogs. Although the characteristics of the antral contractions have not been evaluated in the former studies, they clearly demonstrated that undigested nutrients effectively inhibit gastric tone and total gastric emptying rate by a nervous pathway. Hence, it could be speculated that the ileal brake triggered by fat is of humoral origin, whereas the one triggered by carbohydrate is of nervous origin.

Whereas our experiment univocally demonstrates the humoral nature of the SCFA-induced ileal brake, the inhibitory substance released by the ileum wall is still putative. GLP-1 was not involved since its plasmatic concentrations were unchanged by SCFA infusion. This confirms the secondary role of GLP-1 already suggested in humans (20). On the contrary, the increased plasmatic PYY concentration after SCFA infu-
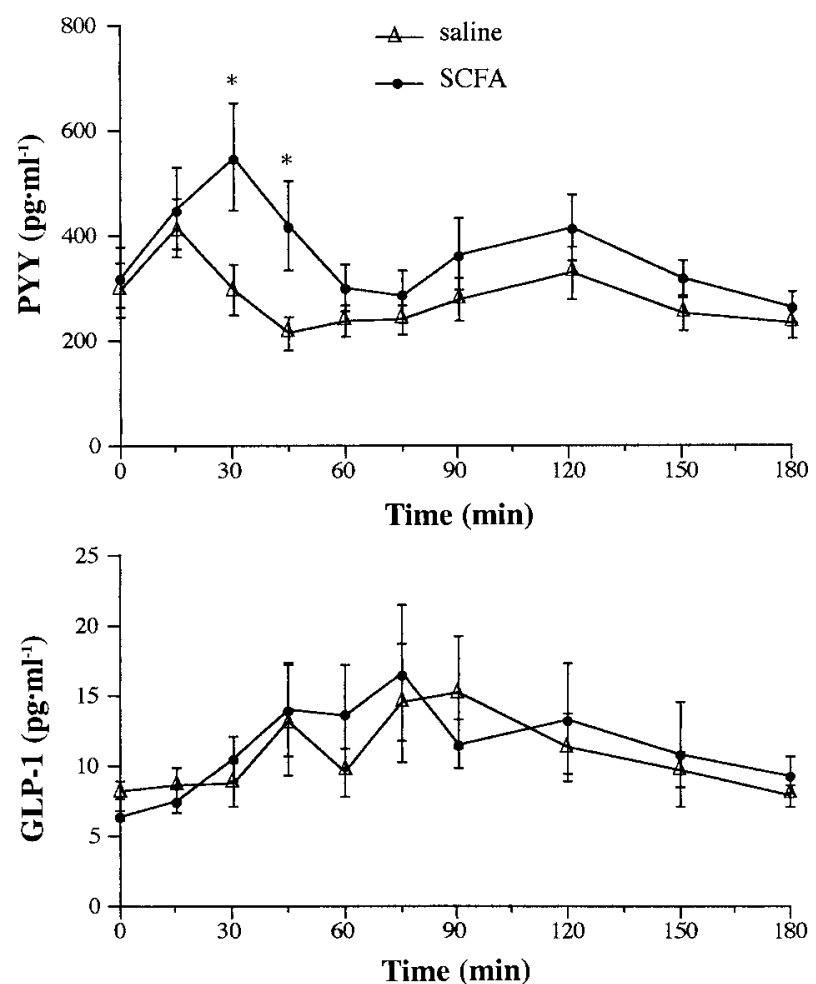

Fig. 5. Plasma concentrations of peptide YY (PYY) and glucagon-like peptide-1 (GLP-1) during ileal infusion of SCFA or saline in group II (innervated loops). Plasma PYY levels were about doubled at 30 and $45 \mathrm{~min}$ after the onset of SCFA infusion. Plasma GLP-1 levels were not significantly modified by ileal SCFA infusion irrespective of sampling time. Values are means $\pm \mathrm{SE} .{ }^{*} P<0.05$ for saline vs. SCFA infusions. 
sion within the innervated or denervated ileal loop is indicative of a possible role for this peptide. Unlike in previous experiments in rats and rabbits $(11,22,24)$, PYY was actually released by the ileum and not as a result of an SCFA-induced colonic stimulation. Surprisingly, PYY concentrations were about doubled during ileal SCFA infusion in pigs, whereas in rats, PYY concentrations were unchanged under the same circumstances (11). However, major interspecies differences in PYY responses have already been mentioned in response to intraluminal nutrient infusions (14). In addition to an overall increase in PYY concentration, supplementary events seem to support a role for PYY in SCFA-induced ileal brake. PYY concentration after SCFA was significantly different from saline $30 \mathrm{~min}$ after the onset of infusion, a delay consistent with the onset of gastric inhibition. Similarly, whereas gastric inhibition lasted 15 min after the completion of the SCFA infusion, PYY peak also extended for a similar duration. Finally, the concept of PYY participation in the ileal brake has been suggested by several groups $(13,16,20)$ and has received major additional support from the finding that immunoneutralization of PYY reversed the inhibitory consequences of ileal infusion of lipids (21).

In conclusion, we have demonstrated that gastric inhibition triggered by SCFA infused in the ileum in quantities similar to those observed during physiological coloileal reflux episodes is of humoral nature. It likely involves PYY release from the ileal mucosa. An extrinsic neuronal pathway, if present, is not mandatory for the reflex to occur.

\section{REFERENCES}

1. Abello J, Ye F, Bosshard A, Bernard C, Cuber JC, and Chayvialle JA. Stimulation of glucagon-like peptide-1 secretion by muscarinic agonist in a murine intestinal endocrine cell line. Endocrinology 134: 2011-2017, 1994.

2. Azpiroz F and Malagelada JR. Vagally mediated gastric relaxation induced by intestinal nutrients in the dog. Am J Physiol Gastrointest Liver Physiol 251: G727-G735, 1986.

3. Babkin BP. Secretory Mechanism of the Digestive Glands. New York: Hoeber, 1944.

4. Basilisco G, Phillips SF, Cullen JJ, and Chiravuri M. Tonic responses of canine proximal colon: effects of eating, nutrients, and simulated diarrhea. Am J Physiol Gastrointest Liver Physiol 268: G95-G101, 1995.

5. Bosshard A, Chery-Croze S, Cuber JC, Dechelette MA, Berger F, and Chayvialle JA. Immunocytochemical study of peptidergic structures in Brunner's glands. Gastroenterology 97: 1382-1388, 1989.

6. Cherbut C, Ferrier L, Roze C, Anini Y, Blottiere H, Lecannu G, and Galimiche JP. Short-chain fatty acids modify colonic motility through nerves and polypeptide YY release in the rat. Am J Physiol Gastrointest Liver Physiol 275: G1415G1422, 1998 .

7. Cuche G and Malbert CH. Ileal short-chain fatty acids inhibit transpyloric flow in pigs. Scand J Gastroenterol 34: 149-155, 1999.

8. Cuche G and Malbert CH. Relationships between cecoileal reflux and ileal motor patterns in conscious pigs. Am $J$ Physiol Gastrointest Liver Physiol 274: G35-G41, 1998.

9. Cuche G and Malbert CH. Short-chain fatty acids present in the ileum inhibit fasting gastrointestinal motility in conscious pigs. Neurogastroenterol Motil 11: 219-226, 1999.

10. Fone D, Horowitz M, Read N, Dent J, and Maddox A. The effect of terminal ileal triglyceride infusion on gastroduodenal motility and the intragastric distribution of a solid meal. Gastroenterology 98: 568-575, 1990.
11. Fu-Cheng X, Anini Y, Chariot J, Voisin T, Galmiche JP, and Rozé C. Peptide YY release after intraduodenal, intraileal and intracoloninc administration of nutrients in rats. Pflügers Arch 431: 66-75, 1995.

12. Fucheng XM, Chariot J, Castex N, Galmiche JP, and Roze C. Mechanisms of peptide YY release induced by an intraduodenal meal in rats: neural regulation by proximal gut. Pflügers Arch 433: 571-579, 1997.

13. Greeley GH, Hashimoto T, Izukura M, Gomez G, Jeng J, Hill FL, Lluis F, and Thompson JC. A comparison of intraduodenally and intracolonically administrated nutrients on the release of Peptide-YY in the dog. Endocrinology 125: 1761$1765,1989$.

14. Hill FLC, Zhang T, Gomez G, and Greeley GH. Peptide YY, a new gut hormone (a mini-review). Steroids 56: 77-82, 1991.

15. Imoto S and Namioka S. VFA metabolism in the pig. J Anim Sci 47: 479-487, 1978.

16. Jian R, Besterman HS, Sarson DL, Aymes C, Hostein J, Bloom SR, and Rambaud JC. Colonic inhibition of gastric secretion in man. Dig Dis Sci 26: 195-201, 1981.

17. Keller J, Runzi M, Goebell H, and Layer P. Duodenal and ileal nutrient deliveries regulate human intestinal motor and pancreatic responses to a meal. Am J Physiol Gastrointest Liver Physiol 272: G632-G637, 1997.

18. Layer P, Holst JJ, Grandt D, and Goebell H. Ileal release of glucagon-like peptide-1 (GLP-1). Association with inhibition of gastric acid secretion in humans. Dig Dis Sci 40: 1074-1082, 1995.

19. Layer P, Peschel S, Schlesinger T, and Goebell H. Human pancreatic secretion and intestinal motility: effects of ileal nutrient perfusion. Am J Physiol Gastrointest Liver Physiol 258: G196-G201, 1990.

20. Layer P, Schlesinger T, Groger G, and Goebell H. Modulation of human periodic interdigestive gastrointestinal motor and pancreatic function by the ileum. Pancreas 8: 426-432, 1993.

21. Lin HC, Zhao XT, Wang LJ, and Wong H. Fat-induced ileal brake in the dog depends on peptide YY. Gastroenterology 110: 1491-1495, 1996.

22. Longo WE, Ballantyne GH, Savoca PE, Adrian TE, Bilchik AJ, and Modlin IM. Short-chain fatty acid release of peptide YY in the isolated rabbit distal colon. Scand J Gastroenterol 26: 442-448, 1991

23. Plaisancie $\mathbf{P}$, Bernard $\mathbf{C}$, Chayvialle JA, and Cuber JC. Regulation of glucagon-like peptide-1-(7-36) amide secretion by intestinal neurotransmitters and hormones in the isolated vascularly perfused rat colon. Endocrinology 135: 2398-2403, 1994.

24. Plaisancie P, Dumoulin V, Chayvialle JA, and Cuber JC. Luminal peptide YY-releasing factors in the isolated vascularly perfused rat colon. J Endocrinol 151: 421-429, 1996.

25. Read NW, MacFarlane A, and Kinsman RI. Effect of infusion of nutrient solutions into the ileum on gastrointestinal transit and plasma levels of neurotensin and enteroglucagon. Gastroenterology 86: 274-280, 1984.

26. Sarr MG, Foley MK, Winters RC, Duenes JA, and DiMagno EP. Role of extrinsic innervation in carbohydrate-induced ileal modulation of pancreatic secretion and upper gut function. Pancreas 14: 166-173, 1997.

27. Siegle M, Schmid H, and Ehrlein HJ. Effects of ileal infusions of nutrients on motor patterns of canine small intestine. Am J Physiol Gastrointest Liver Physiol 259: G78-G85, 1990.

28. Spiller RC, Trotman IF, Higgins BE, Ghatei MA, Grimble GK, Lee YC, Bloom SR, Misiewicz JJ, and Silk DBA. The ileal brake-inhibition of jejunal motility after ileal fat perfusion in man. Gut 25: 365-374, 1984.

29. Walls EK, Phillips RJ, Wang FB, Holst JC, and Powley TL. Suppression of meal size by intestinal nutrients is eliminated by celiac vagal deafferentation. Am J Physiol Regulatory Integrative Comp Physiol 269: R1410-R1419, 1995.

30. Welch IM, Cunningham KM, and Read NW. Regulation of gastric emptying by ileal nutrients in humans. Gastroenterology 94: 401-404, 1988.

31. Wen J, Phillips SF, Sarr MG, Kost LJ, and Holst JJ. PYY and GLP-1 contribute to feedback inhibition from the canine ileum and colon. Am J Physiol Gastrointest Liver Physiol 269: G945-G952, 1995. 